\section{Testing Petiole Sap for Nitrate and Potassium: A Comparison of Several Analytical Procedures}

\author{
Carl J. Rosen, Mohamed Errebhi, and Wenshan Wang \\ Department of Soil, Water, and Climate, University of Minnesota, St. Paul, \\ MN 55108

\begin{abstract}
Additional index words. ion specific electrode, quick tests, plant nutrition, potato, vegetables, Solanum tuberosum
\end{abstract}

\begin{abstract}
An important aspect of establishing critical sap nutrient concentrations for diagnostic purposes is to determine the accuracy of the analytical method used. We compared a Cardy flat membrane $\mathrm{NO}_{3}$ electrode, a Hach portable $\mathrm{NO}_{3}$ electrode, and a Wescan $\mathrm{N}$ analyzer for their ability to determine $\mathrm{NO}_{3}$ concentrations in sap of potato (Solanum tuberosum $\mathrm{L}_{\text {.) }}$ petioles. The Hach and Wescan instruments require diluted sap, while nondiluted sap can be used with the Cardy. Nitrate-N concentrations in nondiluted petiole sap measured with the Cardy electrode were 90 to $120 \mathrm{mg} \cdot \mathrm{L}^{-1}$ higher than the other two methods. Using sap diluted with $0.075 \mathrm{M}$ aluminum sulfate tended to lower Cardy $\mathrm{NO}_{3}$ readings to concentrations closer to the other methods, but made the procedure more complicated for practical use. We also compared a Cardy K electrode with flame emission spectroscopy for determining $K$ concentrations in sap. Using nondiluted sap with the Cardy procedure resulted in $K$ concentrations 200 to $2500 \mathrm{mg} \cdot \mathrm{L}^{-1}$ lower than those determined by flame emission, depending on $K$ concentration of the sap. Diluting sap with $0.075 \mathrm{M}$ aluminum sulfate or deionized water for use with the Cardy electrode resulted in $K$ concentrations similar to those determined by flame emission.
\end{abstract}

Among the recent techniques for $\mathrm{N}$ and $\mathrm{K}$ management in vegetable crops has been the use of petiole sap analysis to determine supplemental fertilizer needs (Hochmuth, 1994; Prasad and Spiers, 1984; Scaife and Turner, 1984). Sap tests to determine nutrient status of crops have been used to a limited degree since the 1920s (Hochmuth, 1994; Jones et al., 1991). Until recently, however, these tests have been considered semi-quantitative, at best. Within the past 15 years, advances have been made in determining sap $\mathrm{NO}_{3}$ and $\mathrm{K}$ in various crops using Merck (Darmstadt, Germany) EM Quant test strips (Coltman, 1987a, 1987b; Coltman and Riede, 1992; Prasad and Spiers, 1984). Critical values for $\mathrm{NO}_{3}$ levels using the EM Quant strips in tomatoes (Lycopersicon esculentum Mill.) (Coltman, 1988; Huett and Rose, 1988) and potatoes (Williams and Maier, 1990) have been established. According to Williams and Maier (1990), EM Quant strips require dilution of the sap and a portable reflectometer to obtain accurate readings and strips have to be periodically checked for variability between and within vials.

Ion-specific electrodes have been available for many years; however, portability has

\footnotetext{
Received for publication 1 Apr. 1996. Accepted for publication 25 July 1996. Scientific Journal Series Paper no. 22,421 Minnesota Agricultural Experiment Station, St. Paul. Mention of products does not imply endorsement of this product over similar products by the Univ. of Minnesota The cost of publishing this paper was defrayed in part by the payment of page charges. Under postal regulations, this paper therefore must be hereby marked advertisement solely to indicate this fact.
}

always been a problem for a quick test application. Scaife and Stevens (1983) compared EM Quant strips with electrode methods and found that $\mathrm{NO}_{3}$ concentrations obtained with the test strips were lower than those obtained with the electrode. In that study, however, differences in sample preparation may have contributed to differences in the results. Both the Hach Company (Loveland, Colo.) and Horiba Instruments (Kyoto, Japan) have commercially introduced portable $\mathrm{NO}_{3}$ electrodes Instruments has also introduced a portable flat membrane $\mathrm{K}$ electrode. The Hach electrode performs in a similar manner to conventional electrodes in that the sample must be diluted to obtain a reading. Vitosh and Silva (1994) have shown that sap $\mathrm{NO}_{3}$ determined by the Hach $\mathrm{NO}_{3}$ electrode is highly correlated with petiole $\mathrm{NO}_{3}$ expressed on a dry weight basis.

The electrode introduced by Horiba Instruments, called the "Cardy meter," has a flat membrane capable of providing a reading for either $\mathrm{NO}_{3}$ or $\mathrm{K}$ concentration in nondiluted sap. Researchers using the Cardy $\mathrm{NO}_{3}$ electrode with nondiluted sap have also shown that sap $\mathrm{NO}_{3}$ is correlated to petiole $\mathrm{NO}_{3}$ expressed on a dry weight basis (Hartz et al., 1993; Hochmuth, 1994; Westcott et al., 1993). The Cardy $\mathrm{K}$ meter has been used to establish sufficiency levels of $\mathrm{K}$ in petiole sap for eggplant (Solanum melongena L.) production (Hochmuth et al., 1993).

While concentrations of $\mathrm{NO}_{3}$ and $\mathrm{K}$ are readily obtained using the electrode methods discussed above, no studies have been conducted to determine the accuracy of the measurements taken. Knowing whether the values obtained with the different techniques are the capable of determining $\mathrm{NO}_{3}$ in plant sap. Horiba "true" values or if they are unique to the instrument or methodology is important when establishing critical values. If the instrument used is precise but not accurate, then the critical values reported would be useful only to those using that particular instrument. However, if the instrument used provides accurate and precise values, then the methods or instruments used to establish critical values are not a significant factor, giving those critical values wider application.

The overall objectives of our experiments were to evaluate the accuracy and performance of 1) the Hach and Cardy $\mathrm{NO}_{3}$ electrodes for determining $\mathrm{NO}_{3}$ in petiole sap and 2) the Cardy K electrode for determining $\mathrm{K}$ in petiole sap.

\section{Materials and Methods}

Nitrate. A 4-year field study on irrigated 'Russet Burbank' potatoes was used to obtain sap for testing the $\mathrm{NO}_{3}$ electrodes. The study was established at the Sand Plain Research Farm at Becker, Minn., on a Hubbard loamy sand (Udic Haploboroll). Ten treatments comprised of four $\mathrm{N}$ rates as urea or ammonium nitrate ranging from 0 to $270 \mathrm{~kg} \cdot \mathrm{ha}^{-1}$ at various times of application were tested. Each treatment was replicated four times in a randomized complete-block design. Fifteen to 30 recently matured leaves (fourth or fifth from terminal) were collected from each plot at 7 - to 14-day intervals from mid-June until midAugust. A total of 240 samples were collected each year. Leaflets were immediately stripped in the field and the petioles were placed in a plastic bag in a cooler. Within $6 \mathrm{~h}$ of collection, petioles were crushed with a Hach press to express the sap. Expressed sap was stored frozen in plastic vials until all analytical procedures could be performed. From a practical standpoint, freezing is not recommended, but because of the many samples to be processed in this study, freezing was necessary to preserve the sap. Freezing did not significantly affect sap $\mathrm{NO}_{3}$ concentrations (data not presented). After thawing, sap was mixed in the vial, pulp was allowed to settle, and sap was decanted into a clean vial for subsequent $\mathrm{NO}_{3}$ determinations.

Two instruments designed for $\mathrm{NO}_{3}$ sap tests were compared: the $\mathrm{Hach} \mathrm{NO}_{3}$ electrode and the Horiba/Cardy $\mathrm{NO}_{3}$ electrode. Nitrate also was determined conductimetrically using a Wescan (nonportable) $\mathrm{N}$ analyzer. This instrument was chosen because it is not sensitive to the same interferences often observed with $\mathrm{NO}_{3}$ electrodes. All $\mathrm{NO}_{3}$ standards were prepared with sodium nitrate.

For the Hach sap test, $1 \mathrm{~mL}$ of expressed sap was mixed with $25 \mathrm{~mL}$ of a $0.075 \mathrm{M}$ aluminum sulfate $\left[\mathrm{Al}_{2}\left(\mathrm{SO}_{4}\right)_{3} \cdot\left(\mathrm{H}_{2} \mathrm{O}\right)_{18}\right]$ solution. The electrode was immersed in the solution and an $\mathrm{mV}$ reading was recorded. Standards with $\mathrm{NO}_{3}-\mathrm{N}$ at 10 and $100 \mathrm{mg} \cdot \mathrm{L}^{-1}$, prepared with $0.075 \mathrm{~m}$ aluminum sulfate background, were used to calibrate the instrument. Unknown readings were related to $\mathrm{NO}_{3}-\mathrm{N}$ concentration (activity) in solution using the Nernst equation (Skoog and West, 1976). 
For the Cardy sap test, a small volume $(\approx 0.1 \mathrm{~mL})$ of nondiluted sap was placed directly on the electrode membrane and a direct reading of $\mathrm{NO}_{3}-\mathrm{N}$ was recorded. The Cardy meter has three scales depending upon the concentration of the sample. Concentrations of $\mathrm{NO}_{3}-\mathrm{N}$ between 0 and 100 can be read to the nearest $1 \mathrm{mg} \cdot \mathrm{L}^{-1}$, those between 100 and 1000 are read to the nearest $10 \mathrm{mg} \cdot \mathrm{L}^{-1}$, and those between 1000 and 10000 are read to the nearest $100 \mathrm{mg} \cdot \mathrm{L}^{-1}$. The instrument was calibrated with $\mathrm{NO}_{3}-\mathrm{N}$ standards at 34 and $450 \mathrm{mg} \cdot \mathrm{L}^{-1}$ with a deionized water background, similar to standards prepared by Horiba Instruments. Although many sap values were above the $450-\mathrm{mg} \cdot \mathrm{L}^{-1}$ range, the slope above this range is linear up to $2000 \mathrm{mg} \cdot \mathrm{L}^{-1}$ (Horiba Instruments, personal communication). The electrode membrane (sensor) was replaced with a new membrane at the beginning of each growing season.

For the Wescan sap test, $1 \mathrm{~mL}$ of sap was mixed with deionized water to a volume of 100 $\mathrm{mL}$. Nitrate-N in solution was determined conductimetrically after reduction to $\mathrm{NH}_{3}$ using granular zinc (Carlson, 1986; Carlson et al., 1990). Readings from diluted solutions were related to $\mathrm{NO}_{3}-\mathrm{N}$ in the sap using a standard curve. Standards ranged from 0 to 28 $\mathrm{mg} \cdot \mathrm{L}^{-1}$ in a deionized water background.

The standard addition technique was used to evaluate the accuracy of each method. Frozen sap collected over 1 year was thawed, bulked into one large sample, and then mixed thoroughly. Standard additions of $\mathrm{NO}_{3}-\mathrm{N}$ at $200,400,600,800$, and $1000 \mu \mathrm{g} \cdot \mathrm{mL}^{-1}$ sap were made by weighing the required amount of sodium nitrate in a 25 -mL volumetric flask and adding enough sap to bring up to volume. All $\mathrm{NO}_{3}$ determinations were made in triplicate using the procedures described above. An additional dilution procedure was included for the Cardy $\mathrm{NO}_{3}$ determinations. For the dilution, $0.5 \mathrm{~mL}$ of sap was mixed with $2 \mathrm{~mL} 0.075$ $\mathrm{M}$ aluminum sulfate solution. $\mathrm{NO}_{3}-\mathrm{N}$ standards of 34 and $450 \mathrm{mg} \cdot \mathrm{L}^{-1}$ also were prepared with aluminum sulfate. A small volume of the mixture was placed directly on the electrode and a concentration reading was recorded.

Potassium. A 2-year field study on irrigated 'Russet Burbank' potatoes was used to obtain sap for determining K concentrations. The study was established at the Sand Plain Research Farm on a Hubbard loamy sand. Nine treatments comprised of five $\mathrm{K}$ rates as potassium chloride or potassium nitrate ranging from 0 to $300 \mathrm{~kg} \cdot \mathrm{ha}^{-1}$ at various times of application were tested. Each treatment was replicated four times. Petiole and sap collection were similar to that described for the $\mathrm{NO}_{3}$ study.

Potassium determination using the Cardy electrode was compared to conventional methods using an atomic absorption spectrophotometer in the flame emission mode (model 3030B; Perkin Elmer, Norwalk, Conn.). Nondiluted and diluted sap preparations also were compared using the Cardy electrode. All $\mathrm{K}$ standards were prepared with potassium chloride.

For the nondiluted sap preparations, the Cardy electrode was calibrated using two stan-
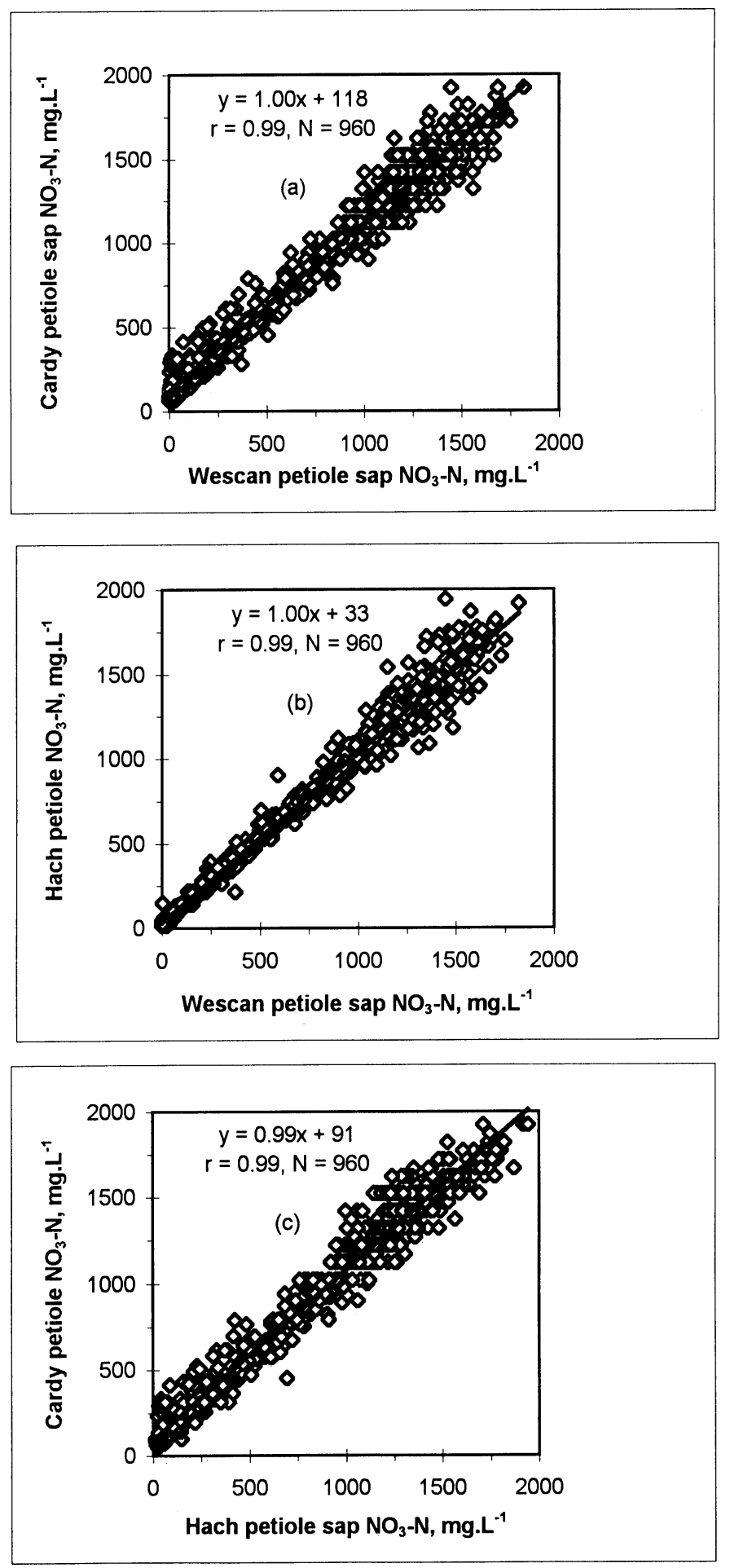

Fig. 1. Correlation between the various analytical techniques used for nitrate determination in petiole sap: $\mathbf{a}=$ Wescan vs. Cardy; $\mathbf{b}=$ Wescan vs. Hach; $\mathbf{c}=$ Hach vs. Cardy.

dard $\mathrm{K}$ solutions, 150 and $2000 \mathrm{mg} \cdot \mathrm{L}^{-1}$, in a deionized water background. A few drops of nondiluted sap were placed on the electrode membrane and a direct reading of $\mathrm{K}$ concentration was recorded. As with the $\mathrm{NO}_{3}$ electrode, the $\mathrm{K}$ electrode has three scales, depending on concentration of the sample. Accuracy of each scale for $\mathrm{K}$ is the same as described for $\mathrm{NO}_{3}$. For the diluted preparations, $1 \mathrm{~mL}$ of sap was diluted to a volume of $10 \mathrm{~mL}$ with $0.075 \mathrm{M}$ aluminum sulfate solution. Standards with $\mathrm{K}$ at 150 and $2000 \mathrm{mg} \cdot \mathrm{L}^{-1}$, prepared with aluminum sulfate, were used to calibrate the electrode. A few drops of the diluted solution were placed on the electrode membrane and a direct reading of $\mathrm{K}$ was recorded. For $\mathrm{K}$ determination using the spectrophotometer, sap was diluted 1:100 with water and Cs at $1 \mathrm{~g} \cdot \mathrm{L}^{-1}$ was added to suppress ionization. The emission mode set at $669.9 \mathrm{~nm}$ was used to determine $\mathrm{K}$ concentration in solution. Standards ranged from 0 to $80 \mathrm{mg} \cdot \mathrm{L}^{-1}$ in a deionized water background with Cs.

As with $\mathrm{NO}_{3}$, the standard addition tech- 
nique was used to evaluate the accuracy of each method. The same procedure was used to obtain a bulked sap sample. Standard K additions of 400, 800, 1200, 1600, and $2000 \mu \mathrm{g} \cdot \mathrm{mL}^{-1}$ sap were made by weighing the required amount of potassium chloride in a $25-\mathrm{mL}$ volumetric flask and adding enough sap to bring to volume. All $\mathrm{K}$ determinations were made in triplicate using the procedures described above. An additional dilution procedure was included for the Cardy procedure determinations. For the dilution, $1 \mathrm{~mL}$ of sap was mixed with $10 \mathrm{~mL}$ water. $\mathrm{K}$ standards of 150 and $2000 \mathrm{mg} \cdot \mathrm{L}^{-1}$ in a deionized water background were used for calibration. A small volume of the mixture was placed directly on the electrode membrane and a concentration reading was recorded.

Statistical analyses. For both studies, linear regression using the least squares method was used to generate the relationships among the various methods (Steele and Torrie, 1980). Differences among slopes and intercepts were determined using 95\% confidence intervals.

\section{Results and Discussion}

Tuber yield increased quadratically with $\mathrm{N}$ and $\mathrm{K}$ fertilizer (data not presented). In these studies sap concentrations of $\mathrm{NO}_{3}$ and $\mathrm{K}$ spanned from below to above the optimum range.

Nitrate. A series of correlations among the three methods for sap $\mathrm{NO}_{3}$ determination are based on 4 years of data covering a wide range of sampling dates and $\mathrm{N}$ fertilizer treatments (Fig. 1a-c). All three methods were highly correlated. Slopes of the regression lines comparing the methods were not significantly different from unity $(P<0.05)$. The intercepts were all significantly different from 0 and from each other $(P<0.05)$. These results suggest that the lines are parallel over the concentration ranges covered and the effects of method on $\mathrm{NO}_{3}-\mathrm{N}$ determination are estimated by differences in the intercept. Therefore, $\mathrm{sap} \mathrm{NO}_{3}-\mathrm{N}$ concentrations measured with the Cardy meter were $118 \mathrm{mg} \cdot \mathrm{L}^{-1}$ higher than those for the Wescan and $91 \mathrm{mg} \cdot \mathrm{L}^{-1}$ higher than for the Hach. The Hach measurements were slightly higher $\left(33 \mathrm{mg} \cdot \mathrm{L}^{-1}\right)$ than those determined by the Wescan.

Recovery of $\mathrm{NO}_{3}$ added to bulk sap ranged from $99 \%$ to $104 \%$ for the Wescan method, $100 \%$ to $105 \%$ for the Hach, $100 \%$ to $106 \%$ for the Cardy nondiluted sap preparation, and $96 \%$ to $108 \%$ for the Cardy diluted sap preparation (Table 1). The zero standard errors associated with Cardy readings from nondiluted sap are due to the fact that when $\mathrm{NO}_{3}-\mathrm{N}$ is above $1000 \mathrm{mg} \cdot \mathrm{L}^{-1}$, the meter is accurate to the nearest $100 \mathrm{mg} \cdot \mathrm{L}^{-1}$. Therefore, the $\mathrm{NO}_{3}-\mathrm{N}$ concentrations can vary by as much as \pm 50 $\mathrm{mg} \cdot \mathrm{L}^{-1}$ and the reading on the Cardy meter would be the same. Differences between the Wescan values and the Cardy nondiluted values are similar to those found in the 4-year study. Hach values were higher than expected but still lower than those for Cardy nondiluted sap preparation. Diluting the sap for the Cardy method generally resulted in lower $\mathrm{NO}_{3}-\mathrm{N}$

Table 1. Recovery of nitrate added to potato petiole sap by four analytical techniques.

\begin{tabular}{|c|c|c|c|c|c|c|c|c|}
\hline \multirow{3}{*}{$\begin{array}{l}\text { Nitrate } \\
\text { added } \\
\left(\mathrm{mg} \cdot \mathrm{L}^{-1}\right)\end{array}$} & \multicolumn{8}{|c|}{ Method } \\
\hline & \multicolumn{2}{|c|}{ Cardy, nondiluted } & \multicolumn{2}{|c|}{ Cardy, diluted } & \multicolumn{2}{|c|}{ Hach } & \multicolumn{2}{|c|}{ Wescan } \\
\hline & $\begin{array}{l}\text { Found } \\
\left(\mathrm{mg} \cdot \mathrm{L}^{-1}\right)\end{array}$ & $\begin{array}{c}\text { Recovered } \\
(\%)\end{array}$ & $\begin{array}{l}\text { Found } \\
\left(\mathrm{mg} \cdot \mathrm{L}^{-1}\right)\end{array}$ & $\begin{array}{c}\text { Recovered } \\
(\%)\end{array}$ & $\begin{array}{l}\text { Found } \\
\left(\mathrm{mg} \cdot \mathrm{L}^{-1}\right)\end{array}$ & $\begin{array}{c}\text { Recovered } \\
(\%)\end{array}$ & $\begin{array}{l}\text { Found } \\
\left(\mathrm{mg} \cdot \mathrm{L}^{-1}\right)\end{array}$ & $\begin{array}{c}\text { Recovered } \\
(\%)\end{array}$ \\
\hline 0 & $900 \pm 0^{z}$ & --- & $875 \pm 14$ & --- & $882 \pm 17$ & $7 \quad--$ & $800 \pm 5$ & --- \\
\hline 200 & $1100 \pm 0$ & 100 & $1067 \pm 17$ & 96 & $1092 \pm 8$ & 105 & $1008 \pm 1$ & 104 \\
\hline 400 & $1300 \pm 0$ & 100 & $1283 \pm 8$ & 102 & $1282 \pm 3$ & 100 & $1217 \pm 12$ & 104 \\
\hline 600 & $1533 \pm 34$ & 106 & $1525 \pm 14$ & 108 & $1497 \pm 2$ & 103 & $1398 \pm 11$ & 100 \\
\hline 800 & $1733 \pm 34$ & 104 & $1717 \pm 8$ & 105 & $1700 \pm 6$ & 102 & $1594 \pm 12$ & 99 \\
\hline 1000 & $1933 \pm 34$ & 103 & $1900 \pm 29$ & 103 & $1922 \pm 2$ & 104 & $1801 \pm 17$ & 100 \\
\hline
\end{tabular}

${ }^{{ }^{z} \text { mean } \pm \text { standard error }}$
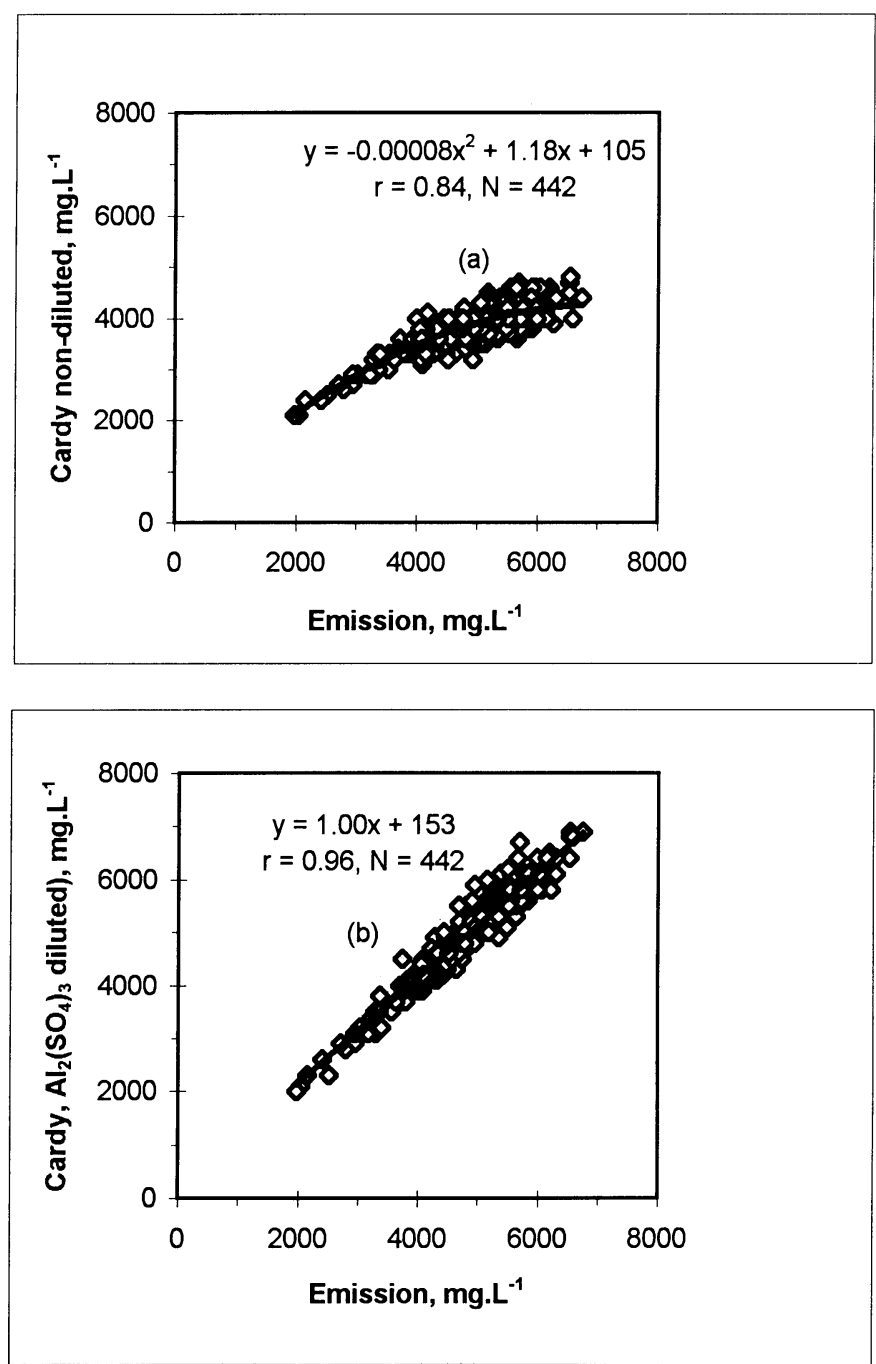

Fig. 2. Correlation between the various analytical techniques used for potassium determination in petiole sap: (a) Emission vs. Cardy, nondiluted sap ; (b) Emission vs. Cardy, sap diluted with $0.075 \mathrm{~m}$ aluminum sulfate.

concentrations than nondiluted sap. These results support the conclusion that using nondiluted sap will, on average, result in slightly elevated values. The question of whether dilution is worth the extra effort needs to be considered when deciding on a method of sap $\mathrm{NO}_{3}-\mathrm{N}$ determination. If accurate sap $\mathrm{NO}_{3}-\mathrm{N}$ readings are desired, then we recommend use of diluted sap. However, this added step may introduce error and makes the procedure less convenient for field use. The overall recovery of $\mathrm{NO}_{3}$ using nondiluted sap was in an acceptable range, suggesting that the extra effort of diluting may not be necessary.
Potassium. The results with the Cardy K electrode were not as encouraging as with the $\mathrm{NO}_{3}$ electrodes. Nondiluted sap K concentrations determined by the Cardy meter were quadratically correlated with diluted sap $\mathrm{K}$ concentrations determined by flame emission (Fig. 2a). In the range of $\mathrm{K}$ concentrations studied, use of nondiluted sap was useful for determining sap $\mathrm{K}$ concentrations in the range of 2000 to $3000 \mathrm{mg} \cdot \mathrm{L}^{-1}$. However, use of nondiluted sap underestimated $\mathrm{K}$ concentrations $\left(\mathrm{mg} \cdot \mathrm{L}^{-1}\right)$ by 250 to 1000 when sap $\mathrm{K}$ concentrations were 3500 to 5000 and by 1000 to 2500 when they were 5000 to 7000 . Diluted 
Soll Management, Fertilization, \& Irrigation

sap $\mathrm{K}$ concentration measured by the Cardy meter corresponded much more closely to the $\mathrm{K}$ concentrations determined by flame emission (Fig. 2b), although the Cardy meter consistently overestimated $\mathrm{K}$ concentrations by $\approx 150 \mathrm{mg} \cdot \mathrm{L}^{-1}$ within the sap $\mathrm{K}$ concentration range studied. While the intercept of $150 \mathrm{mg} \cdot \mathrm{L}^{-1}$ was statistically different from zero $(P>0.05)$, the error over the range of sap $\mathrm{K}$ concentrations studied ranged from $2 \%$ to $8 \%$.

Hochmuth (1994) reported petiole sap K sufficiency ranges of 2500 to $5000 \mathrm{mg} \cdot \mathrm{L}^{-1}$ depending on potato growth stage using the Cardy meter with nondiluted sap. Our K concentrations for potato petiole sap ranged from 2000 to $5000 \mathrm{mg} \cdot \mathrm{L}^{-1}$ (Fig. 2) for nondiluted sap, but the flame emission data showed that the actual values ranged from 2000 to 7000 $\mathrm{mg} \cdot \mathrm{L}^{-1}$. The nondiluted values may still be useful, but only for establishing a relative scale for the Cardy meter.

Standard addition of K to bulk sap resulted in poor recovery of $\mathrm{K}(69 \%$ to $92 \%)$ when nondiluted sap was used, with lowest recovery at the higher rate of standard addition (Table 2 ). Recovery of $K$ added to bulk sap ranged from $98 \%$ to $110 \%$ for flame emission when sap was diluted with water, $96 \%$ to $106 \%$ for the Cardy K electrode when sap was diluted with $0.075 \mathrm{M}$ aluminum sulfate, and $92 \%$ to $108 \%$ for the Cardy K electrode when sap was diluted with water. At concentrations <3000 $\mathrm{mg} \cdot \mathrm{L}^{-1}$, dilution may not be necessary; however, for potato petioles where sap K concentrations are often $>3000 \mathrm{mg} \cdot \mathrm{L}^{-1}$, the sap should be diluted to obtain an accurate $\mathrm{K}$ concentration reading.

The higher recovery of $\mathrm{K}$ with the Cardy electrode when sap was diluted, either with water or $0.075 \mathrm{M}$ aluminum sulfate, may, in part, be the result of a reduction in K activity due to the high ionic strength of nondiluted sap (Skoog and West, 1976). In dilute solutions $(<0.01 \mathrm{M})$, the concentration is about equal to the activity, assuming unity for the activity coefficient. As the ionic strength increases, the activity coefficient decreases, which, in turn, will decrease activity. However, the Cardy $\mathrm{NO}_{3}$ electrode tended to result in slightly higher $\mathrm{NO}_{3}$ concentrations in nondiluted sap compared to diluted sap. If ionic strength were causing the decrease in activity, $\mathrm{NO}_{3}$ should have been affected as well, since the molar concentrations of $\mathrm{NO}_{3}(0.07$ to $0.14 \mathrm{M})$ were similar to the molar concentrations of $\mathrm{K}(0.08$ to $0.18 \mathrm{M})$. Reasons why the Cardy $\mathrm{NO}_{3}$ meter response was not the same as the Cardy $\mathrm{K}$

Table 2. Recovery of potassium added to potato petiole sap by four analytical techniques.

\begin{tabular}{|c|c|c|c|c|c|c|c|c|}
\hline \multirow{3}{*}{$\begin{array}{l}\text { Potassium } \\
\text { added } \\
\left(\mathrm{mg} \cdot \mathrm{L}^{-1}\right)\end{array}$} & \multicolumn{8}{|c|}{ Method } \\
\hline & \multicolumn{2}{|c|}{ Cardy nondiluted } & \multicolumn{2}{|c|}{$\begin{array}{l}\text { Cardy diluted } \\
\text { in water }\end{array}$} & \multicolumn{2}{|c|}{$\begin{array}{l}\text { Cardy diluted } \\
\text { in } \mathrm{Al}_{2}\left(\mathrm{SO}_{4}\right)_{3}\end{array}$} & \multicolumn{2}{|c|}{ Emission } \\
\hline & $\begin{array}{l}\text { Found } \\
\left(\mathrm{mg} \cdot \mathrm{L}^{-1}\right)\end{array}$ & $\begin{array}{c}\text { Recovered } \\
(\%)\end{array}$ & $\begin{array}{l}\text { Found } \\
\left(\mathrm{mg} \cdot \mathrm{L}^{-1}\right)\end{array}$ & $\begin{array}{c}\text { Recovered } \\
(\%)\end{array}$ & $\begin{array}{l}\text { Found } \\
\left(\mathrm{mg} \cdot \mathrm{L}^{-1}\right)\end{array}$ & $\begin{array}{c}\text { Recovered } \\
(\%)\end{array}$ & $\begin{array}{l}\text { Found } \\
\left(\mathrm{mg} \cdot \mathrm{L}^{-1}\right)\end{array}$ & $\begin{array}{c}\text { Recovered } \\
(\%)\end{array}$ \\
\hline 0 & $3967 \pm 33^{2}$ & --- & $5567 \pm 59$ & --- & $5467 \pm 30$ & --- & $5512 \pm 34$ & --- \\
\hline 400 & $4333 \pm 66$ & 92 & $6000 \pm 0$ & 108 & $5850 \pm 48$ & 96 & $5904 \pm 21$ & 98 \\
\hline 800 & $4600 \pm 0$ & 79 & $6300 \pm 0$ & 92 & $6317 \pm 43$ & 106 & $6298 \pm 28$ & 98 \\
\hline 1200 & $4800 \pm 0$ & 69 & $6767 \pm 70$ & 100 & $6650 \pm 48$ & 99 & $6699 \pm 23$ & 99 \\
\hline 1600 & $5100 \pm 58$ & 71 & $7167 \pm 30$ & 100 & $7150 \pm 70$ & 105 & $7279 \pm 48$ & 110 \\
\hline 2000 & $5367 \pm 66$ & 70 & $7550 \pm 32$ & 99 & $7567 \pm 47$ & 105 & $7501 \pm 38$ & 99 \\
\hline
\end{tabular}

${ }^{\mathrm{z}}$ mean \pm standard error.

meter response can not be determined from this study.

\section{Conclusions}

In conclusion, the quick tests used to determine $\mathrm{NO}_{3}$ and $\mathrm{K}$ in petiole sap can provide accurate readings when diluted sap is used. Testing of nondiluted sap with the Cardy $\mathrm{NO}_{3}$ meter can result in $\mathrm{NO}_{3}$ concentrations slightly higher compared to methods using dilution. However, for practical purposes, the error involved with using nondiluted sap does not appear to be large enough to warrant the added effort of dilution. For the K Cardy meter, use of nondiluted sap can result in $\mathrm{K}$ concentrations 200 to $2500 \mathrm{mg} \cdot \mathrm{L}^{-1}$ lower compared to diluted sap, with greatest discrepancy at higher $\mathrm{K}$ sap concentrations. Dilution of the sap is, therefore, necessary to determine accurate sap $\mathrm{K}$ concentrations.

\section{Literature Cited}

Carlson, R.M. 1986. Continuous flow reduction of nitrate to ammonia with granular zinc. Anal. Chem. 50:1528-1531.

Carlson, R.M., R.I. Cabrera, J.L. Paul, J. Quick, and R.Y. Evans. 1990. Rapid direct determination of ammonium and nitrate in soil and plant tissue extracts. J. Plant Nutr. 21:1519-1529.

Coltman, R.R. 1987a. Sampling considerations for nitrate quick tests of greenhouse grown tomatoes. J. Amer. Soc. Hort. Sci. 112:922-927.

Coltman, R.R. 1987b. Yield and sap nitrate responses of fresh market field tomatoes to simulated fertigation with nitrogen. J. Plant Nutr. 10:1699-1704.

Coltman, R.R. 1988. Yields of greenhouse tomatoes managed to maintain specific petiole sap nitrate levels. HortScience 23:148-151.

Coltman, R.R. and S.A. Riede. 1992. Monitoring the potassium status of greenhouse tomatoes using quick petiole sap tests. HortScience 27:361-364.
Hartz, T.K., R.F. Smith, M. LeStrange, and K.F. Schulbach. 1993. On-farm monitoring of soil and crop nitrogen status by nitrate selective electrode. Commun. Soil Sci. Plant Anal. 24:2607-2615.

Hochmuth, G.J. 1994. Sufficiency ranges for nitrate-nitrogen and potassium for vegetable petiole sap quick tests. HortTechnology 4:218-222.

Hochmuth, G.J., R.C. Hochmuth, E. Hanlon, and M. Donley. 1993. Eggplant yield in response to potassium fertilization on a sandy soil. HortScience 28:1002-1005.

Huett, D.O. and G. Rose. 1988. Diagnostic nitrogen concentrations for tomatoes grown in sand culture. Austral. J. Expt. Agr. 28:401-409.

Jones, J.B., B. Wolf, and H.A. Mills. 1991. Tissue testing, p. 99-104. In: Plant analysis handbook. Micro-Macro Publ., Athens, Ga.

Prasad, M. and T.M. Spiers 1984. Evaluation of a rapid method for plant sap nitrate analysis. Commun. Soil Sci. Plant Anal. 15:673-679.

Scaife, A. and K.L. Stevens. 1983. Monitoring sap nitrate in vegetable crops: comparison of test strips with electrode methods, and effects of time of day and leaf position. Commun. Soil Sci. Plant Anal. 14:761-771.

Scaife, A. and M. Turner. 1984. Plant analysis and sap testing. p. 15-18. In: J.D. Robinson (ed.). Diagnosis of mineral disorders in plants. vol. 2. Vegetables. Chemical Publ., New York.

Skoog,D.A. and D.M. West. 1976. Fundamentals of analytical chemistry. 3rd ed. Holt, Rinehart, and Winston, New York.

Steel, R.G. and J.H. Torrie. 1980. Principles and procedures of statistics. 2nd ed. McGraw-Hill, New York.

Vitosh, M.L. and G.H. Silva. 1994. A rapid petiole sap nitrate-nitrogen test for potatoes. Commun. Soil Sci. Plant Anal. 25:183-190.

Westcott, M.P., C.J. Rosen, and W.P. Inskeep. 1993. Direct measurement of petiole sap nitrate in potato to determine crop nitrogen status. J. Plant Nutr. 16:515-521.

Williams, C.J. and N.A. Maier. 1990. Determination of the nitrogen status of irrigated potato crops II. A simple on farm quick test for nitratenitrogen in petiole sap. J. Plant Nutr. 13:985993. 